\title{
Sexuality and power in contemporary Italy: subjectivities between gender norms, agency and social transformation
}

\author{
Elena Zambelli, ${ }^{* 1}$ Arianna Mainardi ${ }^{* 2}$ and Andrea Hajek ${ }^{* 3}$ \\ ${ }^{I}$ Faculty of Law, Vrije Universiteit, Amsterdam \\ ${ }^{2}$ Institute of Humanities and Social Sciences of the Scuola Normale Superiore \\ ${ }^{3}$ Independent scholar
}

(Received 1 February 2018; final version accepted 28 February 2018)

\section{Introduction}

In recent years, the social and legal norms disciplining gender and sexuality have been a prime terrain for political struggles. There have been some notable successes, such as the wave of legal reforms which have enshrined the rights of same-sex couples to enter into different types of intimate unions - albeit in different forms and with different rights in different countries. Other forms of gender-based discrimination, however, remain widespread, attesting to the persistence of the norms which organise social relationships into power-laden hierarchies. In particular, mainstream media have recurrently, albeit selectively, highlighted cases of sexual abuse and harassment in which its protagonists were mainly men in powerful positions demanding, expecting, and/or forcing sex in 'exchange' for access to economic assets they controlled.

At the time of writing this Introduction, in fact, a new sexual scandal erupted following a report in the New York Times, which provoked a wave of accusations of sexual harassment and rape against the successful Hollywood film producer, Harvey Weinstein. As the Contexts and Debates discussion by Andrea Hajek opening this special issue will highlight, in Italy, by contrast, the echoes of this rebellion against sexual violence have taken a peculiarly nationalist and chauvinist turn. Among the first accusers of Weinstein, in fact, was the Italian actress Asia Argento. In contrast to the way in which other actresses were treated in the (international) press, in Italy Argento received much criticism, and only very few voices have dared to question the gendered relations of power that make this form of sexual abuse both possible and widespread. ${ }^{1}$ In fact, victim blaming and 'slut shaming' occur regularly in Italian society, in diverse work settings and geographical locations, online as well as offline - as the contribution of Mainardi in this special issue will discuss. Particularly illustrative is the case of a 13-year-old girl who was raped over a two-year period by a group of young men from her home town. Among the reasons for the delayed denunciation of the abuse was the powerful position of some of her abusers, who included the son of a local carabiniere. More importantly, when the girl eventually found the courage to report them, many people - especially in her home town - failed to empathise with her ordeal, expressing judgements best summarised by the town's mayor: 'Quella se l'è andata a cercare' ('she brought it upon herself'). ${ }^{2}$ Another infamous case that tragically epitomises the

*Emails: elena_zambelli@soas.ac.uk; arianna.mainardi@gmail.com; andreahajek@gmail.com 
breadth and depth of these gendered judgements and stereotypes and their effects on women's lives, is that of the reversal in the Court of Appeal of the sentence against seven young men accused of having raped a young woman: the ruling stated that the verdict had been overly dependent on the alleged unreliability of the accuser, due to her supposedly 'uninhibited' sexual conduct. ${ }^{3}$

These examples show that, rather than questioning the social norm according to which men naturally are, and ought to be, sexual predators, in Italy there remains a strong belief that it is women who should cope with this problem by choosing whether to constrain their mobility and freedoms, or to face the pain that life might throw at them. As Gail Pheterson aptly illustrated, in fact, the 'whore stigma' does not only label women who sell sex for money in different forms and spaces, but also women who go 'out at night alone, on dark streets, dressed to attract male desire' $(1993,46)$. This gendered judgement is further rooted in the contemporary neoliberal emphasis on individual choice and responsibility, to which we briefly refer later. As several of the contributors to this special issue demonstrate, in contemporary Italy the whore stigma remains a powerful and widespread disciplinary technology (Foucault 1977), which contributes to the creation of 'Woman' as a subject, positioned along the male-defined 'good/bad woman' binary. Mainstream media reports and social media commentaries on cases of male sexual violence against women and girls, for example, constitute endless variations within the same interpretative frame.

The way in which Asia Argento has been pilloried, while her male abuser is let off the hook, finds many echoes in Italy's recent history. In particular, it replicates the ways in which the media framed the sexual scandals surrounding the last years of Silvio Berlusconi's premiership (Dominijanni 2014). At that time, it was not the im/propriety of his sexual conduct as a politician and as a private citizen that was the subject of public scrutiny, but rather the im/morality of the women who opted to use - in different ways, spaces and forms - their heterosexual desirability for personal gain. Such cases, then, offer what we consider a compelling prompt for the discussion of sexual freedom at a time when critical battles for self-determination in matters of sexuality and gender have been only partially won, as the contributors to this special issue will show. In order to better understand the current state of affairs as well as contemporary reactions to the achievements of feminism in these areas, we first provide a brief historical overview of the struggles around sexual freedom and self-determination since the 1960s.

\section{Feminist battles for sexual self-determination in postwar Italy}

It is, in fact, with the rise of a new feminist movement in Italy, in the second half of the 1960s, that the 'personal becomes political', and sexual self-determination becomes a prime political goal. Although early feminists fought for women's equality and rights (for example maternity rights), they were restrained by conservative attitudes about sexuality, the firm belief in women's primarily role as mothers, and the 'pressure' of respectability (Willson 2010, 40; 42). In a similar vein, postwar women's associationism and political activism engaged with issues pertaining more to emancipation, welfare and working rights, than to sexuality or reproductive rights (Hajek 2018). Nevertheless, in the 1950s and 1960s the boundaries between private and public were slowly beginning to dissolve and, although sexuality for women was still bound to marriage, it was very much a period of transition (Willson 2010, 126). Think, for example, of the publication of Gabriella Parca's bestselling book Le italiane si confessano (1959), which revealed the anxieties and desires regarding sexual norms of many Italian women at the time (Morris 2006). ${ }^{4}$ Similarly, trials such as that of Franca Viola who, instead of accepting reparatory marriage, denounced her 
rapist and won the case, or scandals involving celebrities (Haworth 2017), all helped bring traditionally private matters into the public arena.

Towards the end of the 1960s and throughout the 1970s, new approaches to sexuality and reproduction developed. This happened partially in response to the postwar feminist politics of emancipation, deemed insufficient and inappropriate for a true liberation of women by the new feminist movement, ${ }^{5}$ and partially in concurrence with the rejection of the traditional family model and the idea of sexual liberation so commonly associated with the 1968 experience. At the same time though, the 1968 movement proved a limitation for women as it reproduced gender stereotypes and discrimination, opening women's eyes to the widespread nature of sexism and disparity among the sexes even within the radical left (Hajek 2018). It is in this context that the Italian women's movement developed new theories and practices focusing on the body, sexuality and sexual health, encouraged also by transnational connections with feminists from France and the USA in particular.

The influence of French feminism can be located in the importance given to women's sexual difference and the body as a point of departure for the understanding of women's sexuality. Thus during a series of international encounters in France and Italy, Italian feminists were deeply affected by the experience of living in women-only communities and experimenting with homosexual relations (Lussana 2012, 75; Hajek 2018). But the new sensibility towards sexuality that Italian feminism developed in this period was also very much concerned with the assertion of female pleasure, with the 'discovery' of the 'clitoridean' - as opposed to 'vaginal' - orgasm, most famously described in Carla Lonzi's classic text, La donna clitoridea e la donna vaginale (1971). Thus female pleasure was separated from the reproductive act: 'The claim to a clitoridean orgasm gave women a sense of challenge, of taking possession of sexual pleasure not linked exclusively to procreation' (Giachetti 2005, 97).

Feminists also adopted the so-called self-help practices introduced to Italy by American women, which responded to a desire to take back control over one's body through knowledge. Self-help is the physical self-examination that women's groups in the USA began practising in response to the failure of the medical profession to meet women's needs, and by way of sharing experiences and knowledge among women. In 1972 and 1973, two leading figures of the Los Angeles Feminist Women's Health Center performed a series of visual demonstrations of self-help organised in Rome (Stelliferi 2015). Our Bodies, Ourselves, the famous women's health manual published by the Boston Women's Health Book Collective and translated into Italian in 1974, further contributed to the diffusion of self-help practices in Italy, which nourished the development of autocoscienza (self-awareness) that Italian feminists promoted as a practice aiming to transcend the male-defined boundaries of their subjectivities and experiences (Sanchez and Sevillano, 2006). As such, self-help practices contributed to the 'formation, sexual education and the presa di coscienza of an entire generation of women' (Stelliferi 2015, 41).

The battle to regain control over and knowledge of women's bodies also reverberated in the creation of alternative medicine groups; in the setting up of self-managed consultori (women's health centres) $;^{6}$ and in the search for alternative forms of giving birth, again inspired by international publications such as Frédéric Leboyer's Birth without Violence (1975). In the second half of the 1970s, this battle became more visible and public, for example in the mass mobilisation for legal abortion co-ordinated by the Comitato romano per la liberalizzazione dell'aborto e della contraccezione (Lussana 2012, 72). In the same period the so-called Circeo massacre and the subsequent trial, fuelled further feminist actions in the public sphere, such as the "reclaim the night' marches and attempts to change legislation. ${ }^{7}$ For example, the popular initiative bill that was presented to parliament in 1980 to redefine rape as a crime against the person and not against 
morality obtained 300,000 signatures (Willson 2010, 163) - although the battle to approve it was only won in $1996^{8}$

Nevertheless, important legal reforms were made throughout the 1970s, in particular with regard to the separation between sexuality, reproduction and the family. In 1970, for example, divorce was legalised, and the great defeat of the Christian Democrats in the abrogative referendum of 1974, when nearly 60 per cent of Italians voted to retain the divorce law, shows just how society had changed. ${ }^{9}$ It also demonstrates that, although the feminist battles revolved around private and intimate issues, they were considered in all senses a political battle, 'a way of liberating female sexuality from the bridles of patriarchy' (Stelliferi 2015, 42). Sexuality, then, was without doubt one of the arenas in which the feminist movement was most successful in this decade.

At the same time, however, feminist struggles for self-determination in the area of sexuality and reproductive rights proved highly problematic and, as Maud Bracke has argued (2014, 215), too much of a challenge to patriarchy. Consequently the state tried to regain control over women's bodies, a process which started in the same years that some of the most important feminist battles for self-determination were won. Thus, following the 1975 law on the consultori, most of the self-managed, feminist women's health centres closed down. Similarly, the legalisation of abortion - in 1978 - was limited by important restrictions such as the conscientious objection of doctors, the percentage of which is still one of the highest in Europe. ${ }^{10}$

Feminism became further institutionalised in the 1980s, with the spread of equal-opportunities politics and academic feminism, while radical and autonomous forms of feminism struggled to survive. Theories of sexual difference began to circulate in feminist circles: they proclaimed a difference manifested in the sexed bodies of women, and the existence of a 'symbolic mother' in contrast to the symbolic male patriarchal order. As Cossutta's contribution in this special issue illustrates, this focus on the maternal figure, and on women's bodies considered by definition in relation to motherhood, has given voice to critical positions - in more recent times - on surrogacy practices, in particular in the context of the debate on the civil-unions law and stepchild adoption.

A second issue relating to sexual self-determination that has proved, and remains, highly contested in feminist circles, is the meaning of women's use of their bodies and sexuality in exchange for money and power. Since the late 1970s, feminist activists and scholars in several Western countries have been engaged in the so-called 'sex wars' (Chapkis 1997), wherein prostitution has functioned as a trope to discuss the meaning of, and the means to pursue, women's liberation. One side in this highly polarised debate - generally those labelled 'radical feminists' posits that prostitution is an 'integral part of patriarchal capitalism' (Pateman 1988, 189) and the 'cornerstone' of 'institutionalized sex inequality' (MacKinnon 2011, 273). On the opposite side, a composite of subjects broadly grouped under the label of 'sex radical feminists' or 'pro-sex feminists' consider that sex can be voluntarily, freely, and legitimately performed and exchanged for money, amounting to a form of labour whose morality is simultaneously claimed and signalled through the etymological shift from 'prostitution' to 'sex work' (see for example Chapkis 1997; Agustín 2007; Weitzer 2010).

In Italy, this debate entered the public arena in the early 1980s, after two women who worked as street sex workers - Carla Corso and Pia Covre - denounced the abuses that they experienced and witnessed while working close to the US military base of Aviano (Corso 1991, 173). The birth of the Comitato per $i$ Diritti Civili delle Prostitute was accompanied by an early engagement with feminists, ${ }^{11}$ in a conversation on the intersection of sexuality, freedom and the market that continues into the present. ${ }^{12}$ The Committee's manifesto (1983) opened with the statement that 'we live in a society in which the right to free sexuality is constantly denied', and concluded with the request for 'the right to use and manage our bodies as we wish, in the factory as in the street, 
as women, mothers, sisters, wives, artists, AND CITIZENS OF THE ITALIAN REPUBLIC.' The importance of overcoming reductionist dichotomies that juxtapose sexual oppression and sexual liberation, victimhood and empowerment, coercion and freedom, constitutes the background of the contributions by Gribaldo, Zambelli, Tagliavia, and Mainardi to this special issue. Women's agency, in fact, unfolds within a contemporary context deeply moulded by the neoliberal urge to turn everything we own, including our bodies, into commodities. With the concept of 'erotic capital', for example, Catherine Hakim (2011) invites women to think of their sexuality as a socioeconomic asset, based on the assumption that what she labels as the natural 'male sex deficit' puts them perennially in search of sex and therefore more likely to pay for it.

\section{Gendered subjectivities in neoliberal times}

Processes of economic and cultural globalisation, the expansion of education, and changes in the labour market have created new possibilities for women's expression and action. Simultaneously, girls and women have become the object of increasing attention from media and public discourse. These processes lead to new forms of governmentality (Foucault 1976). In the context of this special issue, the concept of postfeminism allows us to think more broadly about how social transformation processes intertwine with gender relations. However, the debate around the concept - both inside and outside academia - is complex, as partly mirrored here in how contributors nuance its discussion differently.

Postfeminism has been used to mark a generational discontinuity with other forms of feminism and to define the birth of a new feminism, that of the so-called 'third wave' (Genz 2006), which embraces 'femininity/sexuality as an expression of female agency and self-determination' (Genz and Brabon 2009, 12). It is nonetheless difficult to classify univocally what it is that constitutes the 'new'. Indeed, contemporary research highlights rather the connections and continuities between these most recent feminisms and 'second-wave' feminism (Magaraggia et al 2005, Magaraggia and Vingelli 2015). Furthermore, other scholars agree in defining 'postfeminism' as something more complex and not reducible to a phase or a discourse within feminisms.

Postfeminism is also used to describe a context in which key objectives of second- wave feminism have been selectively incorporated, revised and depoliticised, mainly through their translation into an individualistic discourse. Through ideas of emancipation, freedom and choice, women are actually re-placed within rigid gender categories. The control to which women would be subjected is no longer framed as an obligation, but rather as a choice. In this vein, postfeminism is linked to the concept of backlash. Susan Faludi's analysis of American mainstream culture (1991) revealed the ways in which it promotes a demeaning and stereotypical image of femininity, producing a subject, 'woman', recognisable through the categories of consumer and commodity. She argued, therefore, that this rhetorical device constitutes a counterattack on feminism. By trivialising and ridiculing feminist claims, this backlash not only excluded them from media and public discourses but also considered feminist struggles to be the very cause of the failure of female empowerment (Mascat 2012). Through the depoliticisation of the relationships between women, new forms of sexism were justified and reproduced. Thus, the concept of backlash entered the language of gender and feminist studies to describe the spread of new forms of sexism supported by a 'girl power' that was commodified, and which rejected the claims pursued by feminist movements in previous decades.

Angela McRobbie (2007) has complicated the notion of backlash. In particular, she questions the process by which a feminist political discourse has been co-opted and absorbed by the neoliberal agenda, where concepts such as choice, voice and empowerment have been emptied of 
their political dimension and reduced so as to be in harmony with a neoliberal vision of the subject. McRobbie argues that the media and popular culture have incorporated some feminist claims by turning them into an individualised form of the self; thus, feminism as a collective ethos and movement is considered no longer necessary. In order for women and girls to be free and achieve their goals they must, somehow, be 'post-feminist'. In this scenario, McRobbie describes the existence of a new sexual contract that proposes, in particular to young women, a certain level of freedom based on their access to consumer culture. At the same time, this contract requires power relations based on gender, race and class to remain invisible and therefore unquestionable. Nevertheless, while structural inequalities are far from disappearing, they are more complicated to unravel because they are increasingly intertwined with the notion of individual choice which, following a Foucauldian understanding of power, requires a more active participation of the subject in her/his own regulation.

The relationship between gender and the neoliberal system has long been at the centre of feminist reflection, which not only dismantled the alleged neutrality of power relations engendered by neoliberalism (Morini 2010), but also investigated the ways in which neoliberalism used feminist emancipatory demands to nurture capitalist accumulation (Fraser 2009; 2013). In sum, it is possible that neoliberalism is always gendered, and women and girls represent its ideal subjects (Gill 2008, 443). ${ }^{13}$ In his examination of the Italian context, Federico Zappino (2016) adds a further element of ambivalence; namely, the intertwining of new possibilities of choice and diversity for multiple subjectivities with renewed conservative values linked to sexuality and family - for instance, the presence in Italy of the Catholic 'anti-gender' movement (Bellé, Peroni and Rapetti 2016). ${ }^{14}$

In recent years, in fact, the public sphere has been traversed by recurrent waves of anxieties over the increasingly visible disjunction between sex, gender and reproduction, manifested inter alia in the strong objections in parliament and in the streets to the recognition of reproductive and child rearing models other than the heterosexual nuclear couple. ${ }^{15}$ After several failed attempts, in 2016 Italy finally endorsed a law legalising same-sex unions (Povoledo 2016) - also acting in response to the European Court of Human Rights' condemnation of Italy for having until then failed to do so (Crispian 2015). Although scholarship debating this lengthy process and its as-yet unsatisfactory outcome is flourishing, ${ }^{16}$ in this special issue the contributions by Voli and Cossutta will focus instead on how the unsettling of the gender binary and the increasing visibility of alternative forms of parenting and families interrogate the relationship between the body, reproduction, and 'nature'.

\section{Outline}

With different academic backgrounds and trajectories, all the contributors to this issue bring a fresh interdisciplinary gaze to the subjects they discuss. The special issue is opened by Andrea Hajek, whose commentary 'Je ne suis pas Catherine Deneuve. Reflections on contemporary debates about sexual self-determination in Italy' explores the specificities of the Italian context within the broader international debates on gender, power and feminisms fuelled by the 'Weinstein scandal'.

The contributions of Alessandra Gribaldo and Elena Zambelli both discuss the agency of Italian and migrant women through an intersectional analysis of power. Gribaldo analyses mainstream discourses of gender and sexuality, focusing on the sexual scandals surrounding the former prime minister Berlusconi in the years preceding his (temporary) exit from the political stage. The article discusses the convergence of notions of women's self-determination with a 
neoliberal and postfeminist urge for women to capitalise on their heterosexual desirability. The erotic and sexual work done by the women involved in the scandals is discussed as the epitome of the broader post-Fordist transformation of work, and the gendered and racialised tropes shaping both the then premier's sexual desire and the opposition to his rule are linked to Italy's unresolved colonial past.

Next, Zambelli discusses how the meanings of women's sexuality are shaped at the intersection between the national imagination, postcolonial legacies, and the contemporary sexualisation of culture and trade. Drawing on ethnographic research among women who worked in different niches of the entertainment and sex markets, the article traces the gendered and racialised male gaze under which women negotiate their agency back to the othering processes which underpinned the establishment of Italy as a nation state and an empire. It also shows how, ambivalently, women might experience the racialisation of their sexuality not only as a painful marker of their otherness, but also as a recognition of the social and economic value of their heterosexual desirability.

The articles by Francesca Martinez Tagliavia and Arianna Mainardi discuss young women's agency and gender performance in a context characterised by the value of their embodiment of heterosexual desirability, fuelled by postfeminist notions of women's freedom and choice, and the stigma surrounding women who actually display sexuality for pleasure and/or for work. Tagliavia's article explores the realm of visuality as a space of contention, where gender relations are continuously negotiated among subjects at the level of their everyday social relations. She does so by exploring the figure of the velina - a central female character in the Italian discussion on media, sexuality and politics - starting from the in-depth interviews she undertook with a young woman who played this role in the past. Refusing to discuss the velina as a merely passive subject in an unequal sexual-economic exchange, the author discusses the ambivalent tensions in which female workers of the entertainment industry are immersed. Hence, on the one hand the article reveals the gender norms implied in the role of velina, and on the other it uses the concept of 'infrapolitics' to unpack the subtle forms of resistance at her disposal to challenge sexual and economic domination.

Mainardi's article draws on her sociological research into the digital practices of young Italian women on social network sites, and specifically on Facebook. Against the background of the contemporary transnational debate on sexualisation and on girls' online sexuality, the article explores how young women navigate online spaces where their visual self-representation is both a means to assert their identity and agency, and a source of concern and stigma. The author discusses the norms reproduced through discourses by the young women interviewed, which juxtapose 'good' and 'bad' girls based on their online display of sexuality, within a cultural context that contradictorily invites girls to 'be sexy' but 'not sexual'. By giving voice to young women themselves, Mainardi makes an important contribution to research on sexuality and sexualisation in contemporary Italy.

The articles by Stefania Voli and Carlotta Cossutta centre on different ways in which the meanings of the human body and experiences of gendered embodiment continue to be the object of intersecting medical and legal disciplinary discourses and technologies. Voli explores the trans experience in contemporary Italy through the lens of their access to citizenship. Starting from an historical analysis of the parliamentary debate that led to the endorsement of the law on the Rectification of Sex-Attribution (Law 164/1982), the article explores the meaning of the legalisation of gender reassignment for the reproduction of, or challenge to, the sex/gender binary, foregrounding the paradox whereby trans people's recognition as citizens of the polis relies on their accepting to be legally defined as pathological subjects. 
Cossutta, finally, discusses the contemporary feminist debate on the practice of surrogacy in the context of the law on medically assisted reproduction (Law 40/2004) and on civil partnerships (Law 76/2016). The article reviews leading Italian feminist intellectuals' objections to surrogacy, which revolve around the symbolic value of the mother-and-child dyad. Subsequently, it discusses how the "invention" of motherhood' in Western Europe, at the end of the seventeenth century, served the mutually reinforcing agendas of the rising nation states and capitalist modes of production. Drawing on the philosophical thought of Angela Putino, the author argues that considering parental social bonds as unquestionable lends support to the reproduction of a heteronorm that excludes diverse kinds of parenting relationships.

\section{Acknowledgements}

We would like to thank the anonymous peer reviewers for their valuable contributions to this special issue, the editors of Modern Italy for their engaged support, and all the contributors for their dedicated and committed work, and for the fruitful conversations it sparked amongst us all.

\section{Note on contributors}

Elena Zambelli holds a doctorate in Gender Studies from SOAS, University of London. Currently, she is working as postdoctoral researcher on the ERC-funded research project 'EUROMIX: Regulating Mixed Intimacies in Europe' at Vrije Universiteit Amsterdam. Her research interests and publications revolve around the anthropology of gender and sexuality, intersectionality, the sociology of work and the body - with a particular focus on sex work - and migration. She is the author of a chapter on pleasure and stigma in sexualised culture, in Female Body Politics: Ownership, Coercion and Agency in Muslim Societies and Beyond, edited by Ruba Salih and Andrea Cornwall (2018).

Arianna Mainardi holds a PhD in Information Society from the Department of Sociology and Social Research, University of Milano-Bicocca. She has been a visiting fellow at the Erasmus University Rotterdam and at the Centre d'Analyse et d'Intervention Sociologique (CADIS), École des Hautes Études en Sciences Sociales (Paris). She has published on political activism and gender issues, girls' digital culture, youth and digital media consumption. Her research interests include Gender and Tech, Body \& Sex, Digital culture, Social Research Methods, and Political Participation. Currently, she is a postdoctoral fellow at the Institute of Humanities and Social Sciences of the Scuola Normale Superiore (Florence).

Andrea Hajek obtained her doctoral degree at the University of Warwick. Since then she has held a number of postdoctoral fellowships, including a British Academy postdoctoral fellowship at the University of Glasgow. She is managing editor of the journal Memory Studies and an associate editor of Modern Italy. She is also a founding member of the Warwick Oral History Network, and an affiliate member of the Centre for Gender History, at the University of Glasgow. Her publications include Negotiating Memories of Protest in Western Europe. The Case of Italy (2013) and the (co-edited) volume Memory in a Mediated World: Remembrance and Reconstruction (2015). Her research interests include cultural and collective memory, digital memories, Italian social movements, 1968, the 1970s, second-wave feminism, gender, oral history, and terrorism in Italian cinema.

\section{Notes}

1. See the discussion by Hajek, which also makes reference to the contemporary struggles of newly established transnational feminist movements such as Non Una Di Meno around issues of sexual self-determination and gender-based violence.

2. http://www.linkiesta.it/it/article/2016/09/12/violentata-e-chiamata-prostituta-il-caso-melito-e-lipocrisiadellitali/31732/. Accessed 13 September 2016.

3. https://abbattoimuri.wordpress.com/2015/07/23/firenze-testo-sentenza-di-assoluzione-per-stupro-di-gruppo-allafortezza-da-basso/ Accessed 31 January 2018. 
4. Parca's bestselling book is briefly discussed in Mainardi's contribution in this special issue.

5. See for example the Manifesto programmatico del Gruppo Demau, the first Italian feminist group, although not yet called feminist at the time and composed of both men and women (Hajek 2018).

6. For a detailed account of the so-called Movimento per la Salute delle donne, see Percovich 2005. On one of the first self-managed women's health clinics (consultori), created by a feminist collective in the San Lorenzo neighborhoud in Rome, see Bracke 2014 and Stelliferi 2015.

7. The Circeo massacre refers to the torture, rape and brutal murder of a young woman, and the attempted murder of a second woman, by three neo-fascists from well-off Roman families, in 1975.

8. Law n. 66/1996, 'Norme contro la violenza sessuale' (Norms against sexual violence).

9. Mark Seymour (2010) has pointed out the important role of postwar women's associationism in this case, demonstrating how Noi donne, the feminist periodical published by the Unione Donne Italiane (UDI), made a 'singular contribution to breaking the Catholic Church's discursive monopoly on the family at a grass-roots level', and which 'laid hitherto unacknowledged foundations for the advances made by Italian women in the wake of the divorce referendum'.

10. Statistics show that around 70 per cent of gynaecologists refuse to practise abortions in Italy. http://www. ansa.it/canale_saluteebenessere/notizie/sanita/2017/02/22/aborto-in-italia-7-ginecologi-su-10-sono-obiettori_ 8e057fe0-efcf-4305-8c87-26a6bf6a946c.html. Accessed 10 January 2018.

11. See for example Gambescia 1983 and Rangeri 1983.

12. Amongst others, see the works of Tatafiore 2012; Staderini 1998; Cutrufelli 1996; Serughetti 2013; Garofalo Geymonat 2014.

13. See Gribaldo's contribution in this special issue.

14. See in this special issue the contributions by Cossutta and Voli, which address the social processes that include and exclude some bodies and subjectivities in favour of others.

15. On this subject see Bellé, Peroni and Rapetti 2015; Zappino and Ardilli 2015; Bernini 2016.

16. Some LGBTQI and feminist movements and intellectuals remain critical of the current law, both because of the terminology used, which de facto refuses to assimilate heterosexual and homosexual marriages and unions, and because of the law's failure to recognise the possibility of stepchild adoption.

\section{References}

Agustín, L. M. 2007. Sex at the Margins: Migration, Labour Markets and the Rescue Industry. London: Zed.

Bellé, E., C. Peroni, and E. Rapetti 2016. 'La natura del gender, il conflitto sulla cittadinanza sessuale tra dicotomie e ambivalenze'. In Il genere tra neoliberismo e neofondamentalismo, edited by F. Zappino, 35-47. Verona: Ombre Corte.

Bernini, L. 2016. 'The "teoria Del Gender" in Italy: A Partisan Talk on a Floating Signifier'. University of Leicester, 20 May. http://www.academia.edu/25522398/The_teoria_del_gender_in_Italy_A_partisan_ talk_on_a_floating_signifier_University_of_Leicester_20_May_2016_, accessed 7 November 2016.

Bracke, M. 2014. 'Our Bodies, Ourselves: the Transnational Connections of 1970s Italian and Roman Feminism'. Journal of Contemporary History 50 (3): 560-580.

Chapkis, W. 1997. Live Sex Acts: Women Performing Erotic Labor. London: Cassell.

Corso, C. 1991. Ritratto a tinte forti, Astrea 34. Florence: Giunti.

Crispian, B. 2015. 'Italy Failing Same-Sex Couples Says European Court'. Reuters, 21 July 2015. http://www.reuters.com/article/2015/07/21/us-italy-gaymarriage-ruling-idUSKCNOPV13220150721, accessed 7 November 2016.

Cutrufelli, M. R. 1996. Il denaro in corpo. Uomini e donne: la domanda di sesso commerciale. Milan: Marco Tropea.

Dominijanni, I. 2014. Il trucco. Sessualità e biopolitica nella fine di Berlusconi. Rome: Ediesse.

Faludi, S. 1991. Backlash. The Undeclared War against American Women. New York: Vintage Books.

Foucault, M. 1976. La volonté de savoir. Paris: Gallimard.

Foucault, M. 1977. Discipline and Punish: The Birth of the Prison. London: Allen Lane.

Fraser, N. 2009. 'Feminism, Capitalism and the Cunning of History'. New Left Review 56: 97-117.

Fraser, N. 2013. Fortunes of Feminism: From State Managed Capitalism to Neoliberal Crisis. Brooklyn, New York: Verso. 
Gambescia, P. 1983. 'Proteggerle o Salvarle?' Il Messaggero 21 February.

Garofalo Geymonat, G. 2014. Vendere e comprare sesso. Bologna: Il Mulino.

Genz, S. 2006. 'Third Way/ve: The Politics of Postfeminism'. Feminist Theory 7 (3): 333-353.

Genz, S., and B. Brabon 2009. Postfeminism: Cultural Texts and Theories. Edinburgh: Edinburgh University Press.

Giachetti, D. 2005. Nessuno ci può giudicare. Gli anni della rivolta al femminile. Rome: DeriveApprodi.

Gill, R. 2008. 'Culture and Subjectivity in Neoliberal and Postfeminist Times'. Subjectivity 25: 432-445.

Hajek, A. 2018 (forthcoming). 'Despite or in debt to 1968? Second-wave feminism and the gendered history of Italy's 1968'. In Gender and 1968: the Historical Experience and Political Legitimacy of Struggle, edited by S. Colvin, and K. Karcher. New York: Routledge.

Hakim, C. 2011. Erotic Capital: the Power of Attraction in the Boardroom and the Bedroom. London: Allen Lane.

Haworth, R. 2017. 'Scandal, Motherhood and Mina in 1960s Italy'. Modern Italy 22 (3): 247-260.

Hipkins, D. 2011. "“Whore-ocracy": Show Girls, the Beauty Trade-Off, and Mainstream Oppositional Discourse in Contemporary Italy'. Italian Studies 66 (3): 413-430.

Lussana, F. 2012. Il movimento femminista in Italia. Esperienze, storie, memorie. Rome: Carocci.

MacKinnon, C. A. 2011. 'Trafficking, Prostitution and Inequality'. Harvard Civil Rights - Civil Liberties Law Review 46 (271): 271-309.

Magaraggia, S., and G. Vingelli 2015. Genere e partecipazione politica. Milan: FrancoAngeli.

Magaraggia, S., C. Martucci, and F. Pozzi 2005. 'The Great Fresco Painting of the Italian Feminist Movements'. Annual Review of Critical Psychology 4: 26-38.

Mascat, J.M.H. 2012. 'Il femminismo a marcia indietro?'. In Femministe a parole. Grovigli da districare, edited by S. Marchetti, J.M.H. Mascat, and V. Perilli. Rome: Ediesse.

McRobbie, A. 2007. 'Top Girls? Young Women and the Sexual Contract'. Cultural Studies 21 (4-5): 718-737.

Morini, C. 2010. Per amore o per forza. Femminilizzazione del lavoro e biopolitiche del corpo. Verona: Ombre Corte.

Morris, P. 2006. 'The Harem Exposed: Gabriella Parca's Le italiane si confessano'. In Women in Italy 1945-60, edited by P. Morris, 109-130. New York: Palgrave.

Pateman, C. 1988. The Sexual Contract. Cambridge: Polity Press.

Percovich, L. 2005. La coscienza nel corpo. Donne, salute e medicina negli anni Settanta. Milan: FrancoAngeli.

Pheterson, G. 1993. 'The Whore Stigma: Female Dishonor and Male Unworthiness'. Social Text 37: 39-64.

Povoledo, E. 2016. 'Italy Approves Same-Sex Civil Unions'. The New York Times, 11 May. http://www. nytimes.com/2016/05/12/world/europe/italy-gay-same-sex-unions.html, accessed 2 November 2017.

Rangeri, N. 1983. 'Per due giorni nessuno si vergogna di frequentare prostitute'. Il Manifesto 18 February.

Sanchez, L. G., and A. B. M. Sevillano 2006. 'Experience, Subjectivity and Politics in the Italian Feminist Movement: Redefining the Boundaries between Body and Discourse'. European Journal of Women's Studies 13 (4): 343-345.

Serughetti, G. 2013. Uomini che pagano le donne - dalla strada al web, i clienti nel mercato del sesso contemporaneo. Rome: Ediesse.

Seymour, M. 2010. 'Steel Capsules and Discursive Monopolies. "Noi donne" and Divorce in Italy, 1945-1965'. Storicamente 6 (10). DOI: 10. 1473/stor77.

Staderini, M. 1998. Pornografie: movimento femminista e immaginario sessuale. Rome: Manifestolibri.

Stelliferi, P. 2015. Il femminismo a Roma negli anni Settanta. Percorsi, esperienze e memorie dei collettivi di quartiere. Bologna: Bononia University Press.

Tatafiore, R. 2012. Sesso al lavoro: la prostituzione al tempo della crisi. Milan: Il Saggiatore.

Weitzer, R., ed. 2010. Sex for Sale: Prostitution, Pornography, and the Sex Industry. New York: Routledge. Willson, P. 2010. Women in Twentieth-Century Italy. Basingstoke: Palgrave Macmillan.

Zappino, F. 2016. Il genere tra neoliberismo e neofondamentalismo. Verona: Ombre Corte.

Zappino, F., and D. Ardilli 2015. 'La volontà di negare. La teoria del gender e il panico eterosessuale'. Il Lavoro Culturale 14 July. http://www.lavoroculturale.org/la-volonta-di-negare/, accessed 3 October 2016. 